\title{
Efficacy of the fungus Beauveria bassiana (Balsamo) Vuillemin on the red palm weevil Rhynchophorus ferrugineus Olivier (Coleoptera: Curculionidae) larvae and adults under laboratory conditions
}

\author{
Monir M. El Husseini(D)
}

\begin{abstract}
The efficacy of a local isolate of the entomopathogenic fungus Beauveria bassiana was tested against the red palm weevil (RPW) Rhynchophorus ferrugineus Olivier (Coleoptera: Curculionidae) larvae and adults by direct spraying of the fungus conidiospores on the targeted stages under laboratory conditions. Larvae and adults were offered their natural food as tissue cuts from inside the same infested date palm trees from which they were collected. Six successive increased concentrations from $6 \times 10^{2}$ to $6 \times 10^{7} \mathrm{spores} / \mathrm{ml}$ were tested. Results revealed that the maximum mortality rates for the treated larvae of 3rd instar. Whatever the tested concentration was, the end mortality reached (100\%). In case of the treated larvae of $L_{7}$, the mortality rate ranged between 45 and $75 \%$ with the remaining individuals survived and formed cocoons in which they all died in the pupal stage. Also, all treated adult weevils died showing that the highest tested concentrations of $B$. bassiana killed the weevils in a shorter time (7 days) than in the tested lower concentrations (11 days). Meanwhile, mortality rates in the control for $L_{3}, L_{7}$, and adult weevils were always (0.0\%).
\end{abstract}

Keywords: Beauveria bassiana, Rhynchophorus ferrugineus, Efficacy, Larvae, Adults

\section{Background}

The red palm weevil (RPW) Rhynchophorus ferrugineus Olivier (Coleoptera: Curculionidae) was recorded for the first time in Egypt by Saleh (1992) attacking the date palm Phoenix dactylifera $\mathrm{L}$. at the eastern desert in the newly reclaimed land at Salhya region, Ismailia Governorate. Hallet et al. (1999) mentioned that transportation of infested young palm trees and offshoots introduced the weevil among other areas. For the same factor, the RPW was spread in many areas in Egypt through the last three decades causing destructive damage to date palm plantations. Falerio (2006) reported 17 palm species as hosts for this weevil in about $50 \%$ of the date palm growing countries. Generally, chemical insecticides with their known

Correspondence: monir.elhusseini@agr.cu.edu.eg;

monirelhusseini45@gmail.com

Centre of Biological Control, Faculty of Agriculture, Cairo University, Giza, Egypt

Springer Open environmental hazards have been used for controlling the adult weevil on the palm tree trucks (Merghem 2011; Abbas 2013). Although sanitation measurements and elimination of infested trees are considered within the control strategies, other effective and environmentally safe control measurements and materials are urgently needed (Abraham et al., 2000). Weevil adult pheromone traps were widely used for monitoring and control of the RPW (Abraham et al., 1998 and 1999 and Falerio et al., 1998). The susceptibility of different stages of the RPW to infection with $B$. bassiana was studied under laboratory conditions by many authors (Aldossary et al., 2009; El Safty et al., 2009; and Dembilio et al., 2010). Field applications by dusting with $B$. bassiana conidiospores proved to be successful in controlling adults of the RPW (Sewify and Fouad, 2006; Sewify et al., 2009 and 2014; and El-Akad et al., 2016). 
The present work aimed to evaluate the efficacy of a local isolate from the entomopathogenic fungus $B$. bassiana against larvae and adults of the RPW under laboratory conditions.

\section{Material and methods}

\section{Conidiospores production of $B$. bassiana}

An isolate of the fungus $B$. bassiana isolated from a naturally infected mole cricket (Gryllotalpa gryllotalpa L.) (El Husseini et al. 2008) was cultured on potato dextrose agar (PDA) medium poured into sterilized Petri-dishes (12 cm in diameter). Inoculated Petri-dishes with a spore suspension of $B$. bassiana were incubated for 15 days at $25{ }^{\circ} \mathrm{C}$. The produced areal conidiospores were harvested from the Petri-dishes by scraping with a spatula and suspended in distilled sterilized water with $0.02 \%$ Tween 80 as a wetting agent in the primary stock suspension, following Rombach et al. (1987). The spore count was determined by using a Neubauer Hemocytometer, and the stock was kept in the refrigerator till needed.

\section{Larvae and adults of RPW}

Larvae of the RPW were collected from three highly infested date palm trees that suddenly fell on the ground at the Experiment Station at the Faculty of Agriculture, Giza, Egypt, in 2017. A large number of adult weevils were present inside the fallen palm trees associated with many larvae in different instars and cocoons having pupae inside. Adult weevils and larvae were collected by hand and transferred in metal boxes to the laboratory at the Centre of Biological Control, Faculty of Agriculture, Cairo University, Giza, Egypt. Due to the great difference in size and age of the collected larvae, the selected ones were categorized in young $(\mathrm{Y})$ (3rd instar $\mathrm{L}_{3}$ ) and older $(\mathrm{O})$ as full-grown larvae (7th instar $\mathrm{L}_{7}$ ). Cut tissue pieces from the inside of the same fallen trees served as a food for both larvae and adults in the laboratory during the experimental period.

\section{Efficacy of B. bassiana versus larvae of RPW}

Six concentrations of $\left(6 \times 10^{2}, 6 \times 10^{3}, 6 \times 10^{4}, 6 \times 10^{5}\right.$, $6 \times 10^{6}$, and $2 \times 10^{7}$ spores $/ \mathrm{ml}$ ) were prepared in distilled water from the stock suspension (containing Tween 80) by successive dilutions. A fine perfume atomizer was used to spray the tested spore concentrations directly onto larvae of the two larval instars $\left(\mathrm{L}_{3}\right.$ and $\mathrm{L}_{7}$ ). The larvae were treated in five replicates per concentration, each of 10 larvae; i.e., 300 young larvae $\left(\mathrm{L}_{3}\right)$ and 300 older larvae $\left(\mathrm{L}_{7}\right)$. After the dryness of the sprayed spore suspension, the treated larvae were transferred, using soft forceps into metal boxes $(10 \times 15 \times 30$ $\mathrm{cm}$ ) with perforated metal cover and provided with cut tissues from date palm trees as food. A control was set of untreated larvae for each instar, i.e., 50 larvae for each and sprayed only with water containing $0.02 \%$ Tween 80. The boxes were kept under laboratory conditions of $25{ }^{\circ} \mathrm{C}$ and $50-60 \% \mathrm{RH}$. Inspection for larval mortality occurred daily for 20 days, and the larvae were provided with food. To prove death by B. bassiana, dead larvae were surface-sterilized for 2-3 $\mathrm{s}$ in formaldehyde and rinsed with sterilized distilled water under aseptic conditions. Thereafter, they were placed in sterilized Petri-dishes furnished with wet sterilized filter paper (Merghem, 2011). The Petri-dishes were kept in self-clip closing polyethylene bags to maintain relatively high humidity and kept at room temperature at $25{ }^{\circ} \mathrm{C}$ and $50-60 \%$ R.H. to allow the development of the fungus.

\section{Efficacy of $B$. bassiana versus adults of RPW}

Five concentrations of $\left(6 \times 10^{3}, 6 \times 10^{4}, 6 \times 10^{5}, 6 \times\right.$ $10^{6}$, and $2 \times 10^{7}$ spores $/ \mathrm{ml}$ ) were tested against the adults. The conidiospore suspensions were applied directly on the adult weevils in Petri-dishes as mentioned earlier. After the dryness of the sprayed suspension, the weevils were transferred into metal boxes (the same as in case of the larvae) and inspected daily among a period of 10 days to supply with food if needed and to record the mortality. The dead adult weevils were treated as that of the dead larvae to prove death by B. bassiana.

\section{Statistical analysis}

$\mathrm{LC}_{50}$ and $\mathrm{LC}_{90}$ were calculated, using the software "Ldp Line" software (Bakr, 2005).

\section{Results and discussion}

\section{Susceptibility of RPW larvae to B. bassiana}

Results showed that the 3rd instar larvae of RPW were highly susceptible to B. bassiana as (100\%) mortality was recorded on the 11th day post treatment for the concentrations $\left(6 \times 10^{2}\right.$ and $6 \times 10^{3}$ spores $\left./ \mathrm{ml}\right)$, on the 10 th day for the concentrations $\left(6 \times 10^{4}\right.$ and $6 \times 10^{5}$ spores/ $\mathrm{ml})$, and on the 7th day post treatment for the concentrations $\left(6 \times 10^{6}\right.$ and $6 \times 10^{7}$ spores $\left./ \mathrm{ml}\right)$ (Table 1$)$. Calculated $\mathrm{LC}_{50}$ and $\mathrm{LC}_{90}$ values were $3.9 \times 10^{2}$ (slope 0.436 ) and $3.7 \times 10^{2}$ spores $/ \mathrm{ml}$ for larvae of $L_{3}$, respectively, based on mortality values at the 6th day post treatment. The older instars $\left(\mathrm{L}_{7}\right)$ showed mortality rates ranged between $45-46 \%$ for the concentrations $6 \times 10^{2}$ and $6 \times 10^{3}$ spores $/ \mathrm{ml}$ and $70-75 \%$ for the concentrations $6 \times 10^{6}$ and $6 \times 10^{7}$ spores $/ \mathrm{ml}$, respectively. The calculated $\mathrm{LC}_{50}$ was $3.6 \times 10^{2}$ spores $/ \mathrm{ml}$ (slope 0.160 ), and the $\mathrm{LC}_{90}$ was $3.7 \times 10^{3}$ spores $/ \mathrm{ml}$ based on mortality values on the 12th day post treatment. Meanwhile, the survived treated larvae of $\left(\mathrm{L}_{7}\right)$ formed their cocoons and developed to pupae; but all pupae and newly formed adults died inside their cocoons with developed symptoms of the White Muscardine caused by infection with B. bassiana (Fig. 1). Accordingly, all treated RPW larvae 
Table 1 Mortality \% among larvae of the RPW R. ferrugineus treated with different concentrations of B. bassiana conidiospores and resulted pupae

\begin{tabular}{|c|c|c|c|c|c|c|c|c|c|c|c|c|c|c|c|c|c|}
\hline & 4 & 5 & 6 & 7 & 8 & 9 & 10 & 11 & 12 & 13 & 14 & 15 & 16 & 17 & 18 & 19 & 20 \\
\hline $6 \times 10^{2} Y$ & 0 & 4 & 11 & 20 & 44 & 60 & 80 & 100 & & & & & & & & & \\
\hline O & 0 & 0 & 0 & 4 & 15 & 30 & 33 & 45 & 45 & 45 & 45 & $0^{*}$ & & & & & 100 \\
\hline $6 \times 10^{3} Y$ & 0 & 5 & 12 & 26 & 49 & 65 & 88 & 100 & & & & & & & & & \\
\hline 0 & 0 & 0 & 0 & 4 & 20 & 35 & 46 & 46 & 46 & 46 & $0^{*}$ & & & & & & 100 \\
\hline $6 \times 10^{4} Y$ & 0 & 8 & 14 & 35 & 50 & 82 & 100 & & & & & & & & & & \\
\hline O & 0 & 0 & 4 & 8 & 22 & 35 & 45 & 51 & 52 & $0^{*}$ & & & & & & & 100 \\
\hline $6 \times 10^{5} Y$ & 0 & 11 & 29 & 36 & 45 & 66 & 100 & & & & & & & & & & \\
\hline O & 0 & 0 & 2 & 15 & 30 & 44 & 55 & 56 & 58 & $0^{*}$ & & & & & & 100 & \\
\hline $6 \times 10^{6} Y$ & 0 & 44 & 81 & 100 & & & & & & & & & & & & & \\
\hline O & 0 & 0 & 14 & 20 & 38 & 52 & 65 & 65 & 70 & $0^{*}$ & & & & & 100 & & \\
\hline $6 \times 10^{7} Y$ & 0 & 48 & 83 & 100 & & & & & & & & & & & & & \\
\hline O & 0 & 0 & 18 & 28 & 44 & 60 & 70 & 75 & 75 & $0^{*}$ & & & & & 100 & & \\
\hline Control Y & 0 & 0 & 0 & 0 & 0 & 0 & 0 & 0 & 0 & 0 & 0 & 0 & 0 & 0 & 0 & 0 & 0 \\
\hline O & 0 & 0 & 0 & 0 & 0 & 0 & 0 & 0 & 0 & $0^{*}$ & $0^{*}$ & $0^{*}$ & $0^{*}$ & $0^{*}$ & $0^{*}$ & $0^{*}$ & $0^{*}$ \\
\hline
\end{tabular}

$Y$ young larvae $\left(L_{3}\right), O$ older larvae $\left(L_{7}\right)$

*Pupated in a cocoon

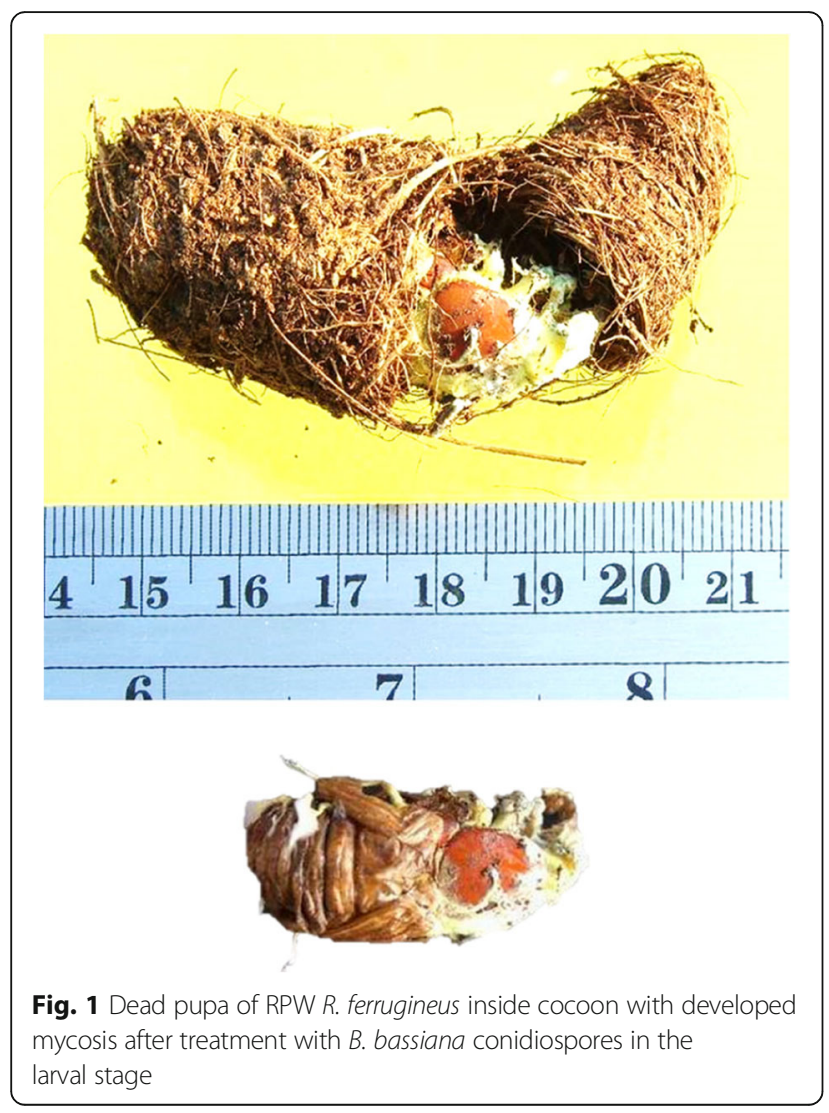

( $\mathrm{L}_{3}$ and $\mathrm{L}_{7}$ ) were killed by all tested concentrations of $B$. bassiana conidiospores. The results revealed a shorter time to kill the young larvae by increasing the fungus concentration from 11 days $\left(6 \times 10^{2}\right.$ spores $\left./ \mathrm{ml}\right)$ to 7 days $\left(6 \times 10^{7}\right.$ spores $\left./ \mathrm{ml}\right)$. The present findings are in line with those of Gindin et al. (2006) and Merghem (2011).

\section{Susceptibility of RPW adults to B. bassiana}

Adults of RPW were found to be highly susceptible to infection with $B$. bassiana (Table 2). All treated adult weevils were killed (100\% mortality) on the 10th, 9th, 8th, and 7th days post treatment at the concentrations $\left(6 \times 10^{3}, 6 \times 10^{4}, 6 \times 10^{5}, 6 \times 10^{6}\right.$, and $6 \times 10^{7}$ spores/ $\mathrm{ml}$ ), respectively. The calculated $\mathrm{LC}_{50}$ was $5.8 \times 10^{1}$ (slope 0.328 ) and the $\mathrm{LC}_{90}$ was $4.7 \times 10^{3}$ spores $/ \mathrm{ml}$. All dead adult weevils were kept for proving death with $B$. bassiana developed the typical symptom of the White Muscardine. The present results are generally common for EPF against different insect species recorded by many

Table 2 Mortality percentage among adults of Rhynchophorus ferrugineus treated with different concentrations of Beauveria bassiana conidiospores

\begin{tabular}{llllllll}
\hline Treatments & \multicolumn{7}{c}{ Mortality percentage among days after treatment } \\
\cline { 2 - 7 } and larvae & 4 & 5 & 6 & 7 & 8 & 9 & 10 \\
\hline $6 \times 10^{3}$ & 0 & 50 & 63 & 81 & 88 & 93 & 100 \\
$6 \times 10^{4}$ & 0 & 55 & 64 & 84 & 91 & 100 & \\
$6 \times 10^{5}$ & 0 & 66 & 85 & 90 & 100 & & \\
$6 \times 10^{6}$ & 0 & 80 & 92 & 100 & & & \\
$6 \times 10^{7}$ & 0 & 80 & 95 & 100 & & & \\
Control & 0 & 0 & 0 & 0 & 0 & 0 & 0 \\
\hline
\end{tabular}


authors, e.g., De la Rosa et al. (2000), Cruz et al. (2005), Ferron (2015), and Jayaprakash and Saranraj (2017). Such high susceptibility of both RPW larvae and adults to the infection with $B$. bassiana may explain the successful field control trials of RPW with $B$. bassiana and also with Metarhizium anisopliae in Egypt and other countries (Merghem 2011 and Abbas 2013).

\section{Conclusion}

Treatment of adults and larvae of the red palm weevil (RPW) $R$. ferrugineus with the conidiospores of the entomopathogenic fungus Beauveria bassiana resulted in a reasonable mortality among larvae and 100\% mortality in contaminated adults. The obtained results confirmed the possibility of using this fungus at least in controlling adults of the RPW by contamination with the conidia of the fungus. In nature, contamination of insects with fungi occurs by contacting the conidiospores of the fungus. This could be reached by dusting the palm trees with the conidia of the fungus to spread the disease among the weevil adults and later to their progeny inside the host palm.

\section{Abbreviations}

O: 7th instar larvae (old); RPW: Red Palm Weevil; Y: 3rd instar larvae (young)

\section{Acknowledgements}

Not applicable

\section{Authors' contributions}

I have written, read, and approved the final manuscript.

\section{Funding}

This work was not supported by any funding body, but personally financed.

\section{Availability of data and materials}

All data are available in the manuscript, and the materials used in this work are of high transparency and grade.

\section{Ethics approval and consent to participate}

Approved.

\section{Consent for publication}

Applicable.

\section{Competing interests}

The author declares that he has no competing interests.

Received: 30 May 2019 Accepted: 6 August 2019

Published online: 27 August 2019

\section{References}

Abbas M.K. 2013. Evaluation methods for red palm weevil control in Egypt during (1992-2010). Palm Pest Mediterranean Conference (AFPP), France, Nice $-16,17$ and 18 January 2013 .

Abraham VA, Al-Shuaibi MA, Faleiro JR, Abozoheira RA, Vidyasagar PSPV (1998) An integrated approach for the management of red palm weevil Rhynchophorus ferrugineus Oliv. a key pest of date palm in the Middle East. Sultan Qaboos University. J Sci Res Agric Sci 3:77-83

Abraham VA, Faleiro JR, Al-Shuaibi MA, Kumar P (2000) A strategy to manage red palm weevil Rhynchophorus ferrugineus Oliv. On date palm Phoenix dactylifera L., its successful implementation in Al-Hassa, Kingdom of Sauidi Arabia. Pestology 24:23-30
Abraham VA, Nair SS, Nair CPR (1999) A comparative study on the efficacy of pheromone lures in trapping red palm weevil Rhynchophorus ferrugineus Oliv. (Coleoptera: Curculionidae) in coconut gardens. Indian Coconut J 30:1-2

Aldossary AA, Shehata ST, Hegazy G, Salem MA, Mariy FMA (2009) Assessment of the entomopathogenic fungus Beauveria bassiana Saudi Arabian isolate (B-SA3) against the developmental stages of the red palm weevil Rhynchophorus ferrugineus (Oliv.). J Agric Sci Ain Shams Univ Cairo 17(1):227-237

Bakr EM (2005) A new software for measuring leaf area, and area damaged by Tetranychus urticae Koch. J Appl Entomol 129(3):173-175

Cruz LP, Gaitan AL, Gongora CE (2005) Exploiting the genetic diversity of Beauveria bassiana for improving the biological control of the coffee berry borer through the use of strain mixtures. Appl. Microbiol. Biotech. 2(3):1-9

De la Rosa W, Alatorre R, Barrera JF, Toreillo C (2000) Effect of Beauveria bassiana and Metarhizium anisopliae (Deuteromycetes) upon the coffee berry (Coleoptera: Scolitidae) under field conditions. J Econ Entomol 93(5)

Dembilio O, Quesad Moraga E, Santiago Alvarez C, Jacas JA (2010) Biocontrol potential of an indigenous strain of the entomopathogenic fungus Beauveria bassiana (Bals.) Vuill. (Ascomycota: Hypocreales) against the red palm weevil Rhynchophorus ferrugineus (Coleoptera: Curculionidae). J Invertebr Pathol 104:214-221

El-Akad S, El-Banna A, Abd El-Wahab S, Abd El-Aal E, Amin S (2016) Effect of Beauveria bassiana and Metarhizium anisoplae on some biological aspect of Pectinophora gossypiella (Saunders) (Lepidoptera: Gelechiidae). Acad J Biol Sci 9(3):31-39

El-Husseini MM, Agamy EA, Mesbah AH, El-Fandary OO, Abdallah MF (2008) Using Beauveria bassiana (Bals.) Vuillemin in spraying and dusting applications for biological control of sugar beet insect pests in Egypt. Egypt J Biol Pest Control 18(2):369-375

El-Safty R, Al-Awash SA, Al bagham S, Shahdad AS, Althra AH (2009) Pathogenicity of the fungus Beauveria bassiana (Bals.) Vuill. to the red palm weevil, Rhynchophorus ferrugineus (Oliv.) (Col.: Curculionidae) under laboratory and field conditions. Egypt J Biol Pest Control 19(1):81-85

Falerio JR (2006) A review of the issue and management of the red palm weevil Rhynchophorus ferrugineus (Coleoptera: Curculionidae) in coconut and date palm during the last one hundred years. Int J Trop Insect Sci 26(3):135-154

Falerio JR, Abraham VA, Al-Shauaibi MA (1998) Role of pheromone trapping in the management of red palm weevil. Indian Coconut J 29:1-3

Ferron P (2015) In: Kerkut GA, Gilbert L (eds) Fungal control-comprehensive insect physiology, biochemistry and pharmacology, Vol.III. Pergamon Press, New York, pp 313-346

Gindin G, Levski S, Glaser I, Soroker V (2006) Evaluation of the entomopathogenic fungi Metarhizium anisopliae and Beauveria bassiana against the red palm weevil Rhynchophorus ferrugineus. Phytoparasitica 34(4):370-379

Hallet RH, Oehlschlager AC, Borden JH (1999) Pheromone trapping protocols for the Asian palm weevil Rhynchophorus ferrugineus (Coleoptera: Curculionidae). Int J Pest Mana 45:231-237

Jayaprakash A, Saranraj P (2017) Agrobeneficial entomopathogenic fungi-Beauveria bassiana. IAJMR 3(2):1051-1087

Merghem A (2011) Susceptibility of red palm weevil, Rhynchophorus ferrugineus (Olivier) to the green muscardine fungus, Metarhizium anisopliae (Metsch.) in the laboratory and in palm trees orchards. Egypt J Biol Pest Control 21(2):179-183

Rombach MC, Humber RA, Evans HC (1987) Metarhizium album a fungal pathogen of leaf and plant hoppers of rice. Trans Br Mycol Soc 37:37-45

Saleh M R A. 1992. Red palm weevil Rhynchophorus ferrugineus Olivier, first recorded in Egypt and indeed in African continent list No.10634 Africa; Collection No. 22563. Int.Inst.Entomol., 56 Queen Gate, London, UK.

Sewify GH, Belal MH, AL-Awash SA (2009) Use of entomopathogenic fungus, Beauveria bassiana for the biological control of the red palm weevil, Rhynchophorus ferrugineus Olivier. Egypt J Biol Pest Control 19(2):157-163

Sewify GH, Belal MH, Saeed MQ (2014) Using pheromone mass-trapping and the entomopathogenic fungus Beauveria bassiana in IPM programs for controlling the red palm weevil Rhynchophorus ferrugineus (Coleoptera: Curculionidae). Egypt J Biol Pest Control 24(1):197-202

Sewify GH, Fouad SH (2006) Integrated control of red palm weevil Rhynchophorus ferrugineus (Coleoptera: Curculionidae). Agric Sci Mansoura Univ 31(4):2415-1426

\section{Publisher's Note}

Springer Nature remains neutral with regard to jurisdictional claims in published maps and institutional affiliations. 